\title{
Implementation of Value Clarivication Tehnique Model Assisted by Image Media in Improving Motivation and Results Learning Education Cityzenship (PKn) Four Graduated on SDN Wonorejo III/314 Surabaya
}

\author{
Anita Dwi Anggraini ${ }^{1)}$, Suhanadji ${ }^{2)}, \mathrm{Rr}$. Nanik Setyowati ${ }^{3)}$ \\ 1), 2),3) Primary Education of Study Program, Postgraduate Student, State University of Surabaya
}

\begin{abstract}
This research is a class action study aimed to determine the motivation and outcome of students ' learning in Citizenship Education (PKn), especially the material of my dwelling area by applying the model Value Clarivication Tehnique (VCT) assisted image media. This research was conducted in class IV of SDN Wonorejo III/314 Surabaya Year lesson 2019/2020 which amounted to 34 students in 3 cycles. The research draft used is class action research (PTK) developed by Kemmis \& Mc. Taggart, covering four stages of 1) planning, 2) Acting $\&$ are, 3) reflecting and 4) revise plan. To determine the effectiveness of the use of VCT models with image media, data processing is carried out through student poll sheets and student activity sheet test Results (LKS) on each cycle. The motivation Data studied at Cycle I of $61.77 \%$ increased by $17.64 \%$ in Cycle II and became $94.12 \%$ in Cycle III. While the learning results experienced an increase from the original only $35.29 \%$ increased by $17.65 \%$ in Cycle I, 20.59 on cycle II and $20.59 \%$ in cycle III to be $94.12 \%$. Thus, the implementation of the learning model VCT with Image Media is stated in accordance to the study of PKn-class IV at SDN Wonorejo III/314 Surabaya because it has exceeded the indicated achievement indicator.
\end{abstract}

Keywords:- VCT Model with Image media support, citizenship Education (PKN), Motivation and learning outcomes.

\section{INTRODUCTION}

PKn learning is aimed not merely to memorize the Pancasila and the Constitution of the Republic of Indonesia Year 1945 (UUD 1945), but how students can implement the values of Pancasila and the CONSTITUTION of NRI in 1945 in everyday life. Through the learning process, especially learning of $\mathrm{PKn}$, teachers must be able to encourage students to be good citizens, citizens who are aware of their rights and obligations and always think critically about the emerging issues in his country (Azis, 2017:127). Efforts to build a personality of Indonesian citizen that is good through learning PPkn, temyata not as expected. In general, Adimasana (in Atmadi, 2000:31) said our educational situation during the last 35 years has less awareness of the value of being the motor drive development of learners toward human life. In line with that, Ruminiati (2007:31) expressed the results showed that 93\% of ELEMENTARY/MI teachers gave the value of PKn raport by taking an average value on the cognitive test alone, while the other $7 \%$ was a combination of psychomotor and affective.

The result of this study indicates that the study of PKn-SD conducted by the teachers less touching the aspect of attitude and behaviour, so that the quality of graduates have not been in the hopes of PKn curriculum. It is also explained by Zuriah (2007:135) that the rise of issues of various parties highlighting the organizing of national education systems that have not been able to produce quality graduates, including an insight Accusingan will be low quality of this graduate has always lead to the success of the learning of PKn. As a proof, there are unpraiseworthy attitudes and behaviors, such as interstudent fights, persecution, drugs, harassment, and so on.

The lack of success of PKn and religion in shaping the moral nation is due to the learning model that teachers applied in error, because the emphasis is only on the realm of cognitive, while the realm of the Afektifrya is only a little touched (Warsono, 2006:2). This is what makes the learning outcomes of PKn-and-religion which is applied in schools especially in elementary school level ineffective. In line with that, the observation of the study done at the beginning of semester II of lesson 2019-2020 by class IV teacher at SDN Wonorejo III/314 also shows less effective learning of moral value in PPkn because of the result of not having a model of proper moral value learning. Teaching moral value in PKn more often only uses lecture methods. Learning that is dominated and mastered or centered on the teacher in the delivery of the material or subject that is Absfrak such as the introduction, development, and practice of concept or value simply by the method of lecture or expositivity alone.

Such learning, apparently not in accordance with the expectations of the PKn curriculum, because it lacks the experience of moral values that can encourage students to reflect on their thoughts and feelings. According to the Adepreciilo (in Atmadi, 2000:77), the value cannot be 
verbally taught, but the students need to be consulted and experience a useful value for themselves. So, when PKnlearning about the material Pancasila and the CONSTITUTION 1945, during the early formative replay of semester II of lesson 2019-2020 was obtained 12 students from 34 students or $35.29 \%$ Grade 4 who had reached a target criteria of minimal submission (KKM) 70 which had been stipulated in class IV of SDN Wonorejo III/314 Tegalsari District of Surabaya and as many as $64.71 \%$ or 22 students received a value of less than KKM (attached test results Appendix I). These low learning outcomes correspond to observations during learning where students look less enthusiastic about learning, easily distracted or less concentration, unfocused, and busy themselves.

From this problem, it can be said that PKn SD need a model of learning moral value that is appropriate and easy to apply, and increase the activity of students in experiencing the values taught, thus allowing the occurrence of internalization and personalization of value into students. Therefore, it is necessary to develop affective learning model using "value clarification technique", which is often called Value Clarification Technique (VCT). According to Elmubarok (2008:70), clarifications of emphasis on the effort to assist students in reviewing their feelings and actions, to raise awareness about their own values. Winataputra (2008:5.37), stating that the VCT model is suitable for implementation in PKn learning, because it has an advantage in affective learning.

To find out how to allow students to have awareness of their values and the values of others in the course of PKn taught by the teacher, then a teacher must have creativity by trying to apply one of the learning models that are considered effective. The VCT learning model in PKnlearning emphasizes on habituation through the value of the values needed to provide students with value experiences to foster a student's attitude toward the object of good value of affective attitude as well as psychomotor attitudes even though verbally.

A learning model will be more maximally used if assisted by the proper use of media. One of the suitable media to be combined with the VCT model is the image media. The image media used in this research is a picture media where the media can capture students to have the same concept of good values in the area where they live. The use of image media can increase the motivation of student learning that will indirectly facilitate students in understanding the ongoing learning materials. An improved understanding of the material will result in increased learning outcomes, thus the application of VCT models with image media will be able to improve the motivation and learning outcomes of students because students are able to experience the experiences related directly and concrete so that the Mehaman gained effective and durable through the delivery of messages contained in the image media.

\section{METHOD}

This research is a class action research (PTK). PTK is a type of action research set in the classroom to obtain scientific solutions in addressing the problems of teaching and learning activities. PTK aims to improve the learning process that starts from the plan of learning, process to learning outcomes. In this case, collaborative teacher conducted class in planning, implementation action and evaluation of results.

This research consists of planning, implementation, observation and reflection conducted in two cycles, in each cycle is done one meeting. The study was conducted in February and March in 2020. The researcher chooses and establishes the research subject is a class IV teacher and grade IV student of SDN Wonorejo III/314 Tegalsari District of Surabaya City with a total of 34 students, a male student of 22 people, and a female student of 12 persons. All students have the same treatment and action.

To fulfill and obtain the data used in this research, a data collection technique is required. The data collection techniques used in this study are as follows.

\section{A. Observation}

Observation is a technique of data collection by means of researchers conducting direct observations of the objects examined. It is intended for researchers to get an overview of the implementation of the VCT model to increase student activity and motivation for PKn-learning.

\section{B. Poll}

Angket is a technique of collecting data that is done by giving a set of Pcrtanyaan or written statements to the respondent to be answered. A poll is provided to students, needed to help complement the observation sheet in terms of measuring the student's motivation and learning for teaching planning in implementing the VCT model.

\section{Evaluation of learning Outcomes}

The learning Data in the form of student worksheets is carried out at the end of each lesson in the test question. Data collection instruments are designed by researchers in such a way as to obtain results in accordance with the context of research.

The analysis of the data to be used is descriptive to explain the data obtained from a learning motivation questionnaire, and the statistical analysis of the correlation of Spearman to know the Antau coefficient of variables, also including double regression. In principle, data analysis methods are used to process data using statistical methods which can be to find conclusions. In this study used analysis of the following data.

\section{* Descriptive percentage analysis}

A descriptive percentage analysis is used to describe the percentage of free variables i.e. learning motivation. The measurements of variables that are revealed are done by providing the student with a score of the poll answers. 
The statement was arranged in the form of Likert scale, with the range from almost always to no-. The range of approval scales divided into 5 parts include: (L) almost always (HS), (2) often (SK), (3) sometimes (KK), (4) occasional never (PS), (5) Never (TP). Each scoring scale is rated as: $\mathrm{HS}=5, \mathrm{SK}=4, \mathrm{KK}=3, \mathrm{PS}=2$ and $\mathrm{TP}=\mathrm{L}$, while statements that do not support the idea (-) are given the inverse score: $\mathrm{HS}=1, \mathrm{SK}=2, \mathrm{KK}=3, \mathrm{PS}=4$, and $\mathrm{TP}=5$.

The scoring score of each question moves from 1 to 5 which corresponds to the scale of Likert (Sugiyono, 2013:135). When a question that supports the idea $(+)$ is answered a, it will acquire a score of 5 and means the motivation of learning is very high, if the question tends to be answered $\mathrm{E}$ will acquire a score I and this states that the motivation to learn is very low. When a statement that does not support the idea (-) is answered a will get a score of 1 , if the statement is likely to be answered E will get a score of 5. To be clearer then the description is depicted in the following table.

\begin{tabular}{|c|c|c|}
\hline Altemative answer & Score & Description \\
\hline & $\begin{array}{c}\text { Statements that not } \\
\text { support the idea }\end{array}$ \\
\hline A & 5 & Very high \\
b & 4 & High \\
c & 3 & Are \\
d & 2 & Low \\
e & 1 & Very low \\
\hline \multicolumn{3}{|c|}{ Statements that do not support the idea } \\
\hline A & 1 & Very high \\
c & 2 & High \\
d & 3 & Are \\
e & 4 & Low \\
\hline
\end{tabular}

Table 1:- Likert Scale scores learning motivation instruments

(Source: Sugiyono, 2013:135)

Because the motivational instrument amounted to 15 items, then the highest score is $15 \times 5=75$. While the lowest score is $15 \mathrm{x} \mathrm{I}=15$. To determine the limit between high learning motivation and low learning motivation used formula:

Score limit $=($ Highest score + lowest score $): 2$

$=(75+15): 2$

$=45$

So students who have a score of 15 to 44 is a low learning motivation, and who has a score of 45 to 75 has a high motivation to learn. To score a real limit of learning motivation is gained from the score calculation of insfrumen evaluation of learning motivation filled students with the formula: Score limit $=$ (Highest score + lowest score): 2. The steps taken in the use of data analysis techniques are as follows:

Collect polls and check the accessories

$>$ Change the qualitative score to a quantitative score for a statement that supports the idea (+) by:

- Answer A was rated 5
- Answer B rated 4

- Answer $\mathrm{C}$ was rated 3

- Answer d given score 2

- Answer e score 1

$>$ Change the qualitative score to a quantitative score for statements that do not support the idea (-) by:

- Answer A was given the score 1

- Answer B rated 2

- Answer C was rated 3

- Answer D rated 4

- Answer E rated 5

$>$ Create Data tabulation

$>$ Entering data into the formula score limit $=$ (Highest score + lowest score): 2.

\begin{tabular}{|c|c|c|}
\hline Number & Score & $\begin{array}{c}\text { Learning Motivation } \\
\text { Criteria }\end{array}$ \\
\hline 1 & $15-44$ & Low motivation \\
\hline 2 & $45-75$ & High motivation \\
\hline
\end{tabular}

Table 2:- Learning Motivation Criteria

(Source: Sugiyono, 2013:135)

\section{RESULTS AND DISCUSSION}

\section{Learning Motivation Cycle I Students}

Based on the results of the completion of learning motivation for students filled after cycle I completed the 10 statements of results There are 21 students of high motivation category or $61.77 \%$, but there are 13 students who are still in the category of low motivation learning or $38.23 \%$. This means that the specified submission has not been reached by $80 \%$. To increase the motivation to study students, planned use of color animated image media According to the age of students who are still in a phase attracted by brightly coloured images, in hopes of optimizing students ' positive activities during learning.

\section{Learning Motivation Cycle II Students}

Based on the results of the filling of learning motivation that filled with students after completion of cycle II learning consisting of 10 statements of results there are 27 students high motivation category or $79.41 \%$, but there are 7 students who are still in the category of low motivation learning or $20.59 \%$. This indicates that the specified submission has not been reached because it is still less than the achievement indicator of $80 \%$. To further enhance the student's learning motivation, it is planned to use color photo image media According to the age of the student who is still in a phase attracted by images capable of representing real objects in the field, with the goal of students ' positive activity during learning can be more optimal.

\section{Learning motivation for student cycle III}

Based on the results of the filling of learning motivation that filled students after completion of cycle study III consisting of 10 statements of results There are 32 students high motivation category or $94.12 \%$, but there are 2 students who are still in the category of low motivation learning or $5.88 \%$. This means that the specified 
submission has been reached which is $80 \%$ and it is declared successful. Research by implementing VCT learning model with photo image media of wits have successfully increased motivation of learning students. This is seen when students follow an explanation of the message in the image with the intention of explaining the benefits to the student. Learning process and student learning outcomes.

\section{Teacher Activity Cycle I}

Based on the results of learning observations before the application of the VCT learning model with image media can be known that the outcome of the overall aspect is uneven with an average value of $58.33 \%$ or at sufficient value. The aspects that get observations with the lowest value are on the aspect of warming/apperception and motivation of students, conveying the purpose of learning, conveying/demonstrating the image, and doing follow-up that only earns a $50 \%$ value. After implementation of VCT learning model with image media assisted increased teacher activity by $10.86 \%$ to $69.19 \%$ on cycle I. Although it has not reached the specified indicators, but teacher activity has influenced the learning process. Of the 12 aspects of the teacher's activity on cycle I, the teacher activity is the lowest in the aspect of conveying the subject matter and conveying the learning objectives. This is because teachers have difficulty directing students to clarify their students ' thoughts on the object being assessed. Aspects of habituation at the beginning of the lesson, warming up/apperception and motivating students, explaining the picture, guiding students to identify the individual diversity in the picture, guiding students to explain the diversity of individuals found in images, convey a case of personability, clarifying the opinions/feelings of students towards value objects, guiding students to conclude the material that has been delivered, closing the lesson, and doing the follow-up has reached an average of $70 \%$ while the highest score found in aspect 11 is to evaluate with an average score of 4 or a percentage of 80 Thus it needs to be repaired in subsequent cycles.

In its execution the teacher was able to provide good enough guidance to the students who have difficulty identifying the behavior in the image so that it makes students more active in learning. It is in accordance with the opinion of Djamarah (2011:109) that a profession as a teacher must possess and master the principles of teaching and always actively applying it in teaching learning activities.

\section{$>$ Master Cycle Activity II}

Based on the results of observing the teacher's activity on cycle II acquired 12 facets, among others: aspects of informing the subject matter, guiding students to identify diversity in the picture, guiding students to explain the diversity of individuals found in the picture, and clarifying the opinions/feelings of students towards the value object obtaining an average score of 3.5 or a percentage of $70 \%$ This is because in associating learning materials with images that teachers use is still experiencing obstacles about the clarity and the hassle of delivering material that is less understandable to students. The highest scoring aspect is in the evaluation aspect with an average score of 5 or $100 \%$. While the other 7 aspects get an average score of 4 or a percentage of $80 \%$. Overall the average score of the teacher's cycle activity was 3.92 or a percentage of $78.33 \%$. When compared with the teacher activity in cycle I, there is an increase in the percentage of $9.14 \%$. This means that the success of the indicator has not been achieved yet exceeds the preset indicators that should be extended to the III cycle.

\section{> Teacher Cycle Activity III}

Based on the results of observation of teacher activity on cycle III acquired results 12 facets between Iain: aspects of guiding students identifying diversity in the picture, guiding students to explain the diversity of individuals found in images, conveying a case of personality and clarifying the opinions/feelings of students towards the value object gaining an average score of 4.5 or a percentage of $90 \%$. While the other 8 aspects are gaining an average score of 5 or a percentage of $100 \%$. Overall the average score of the teacher's cycle activity was 4.83 or a percentage of $96.67 \%$. When compared with the teacher activity in cycle $\mathrm{I}$, there is an increase in the percentage of $20.84 \%$. This means that the success of the indicator has been achieved with the category "excellent " and exceeds the preset indicators.

\section{Student Activity Cycle I}

Based on the results of observations before the use of VCT learning Model assisted by the image media is the following data. Of the 10 aspects of student activity on early findings, acquired students ' activities that occupy the lowest value in the aspect of doing habituation at the beginning of learning, giving the response of heating/apertion, noting the explanation of material points, noting the purpose of learning, identifying the behavior in, response clarification questions to the case being read out, response to the case clarification questions described, 50 2.5 and While the percentage of success aspect describes the behaviour found in the image and concludes the material has been submitted obtained a score of 3 or $60 \%$. Overall, students are attracted by the application of VCT models with the media of images in learning the material of individual diversity in daily life.

\section{$>$ Student Cycle II Activities}

Based on the results of observation of students on the cycle II obtained 10 aspects of the results, among others: response clarification Questions to the case read, explaining the diversity of individuals found in the picture, response to the case clarification questions described, concluded the material submitted, and filling evaluation tools still get a score of 3.5 or $70 \%$ and has not reached the indicator of the compensation of $80 \%$. This is because students are still less confident in self-conveying opinions in response to the case clarification questions described. The highest score is in the 1 st aspect of doing habituation at the beginning of the study at 4.5 or $90 \%$. While the 4 aspects have reached an average percentage of $80 \%$ and have reached the indicator of the submission. Overall in the implementation of study cycle 
II, the average value of students ' activities has increased by $7 \%$ compared with the cycle 1 which is $76 \%$ from the original $69 \%$, but still not be said as complete because it has not fulfilled the indicator of the satisfaction of $80 \%$ and must be extended in cycle III. Overall, students ' activities have been increased and are interested in the process of learning VCT model with the media of the animation of a drawing to the degree of activity of students category "Good.

\section{$>$ Student Cycle III Activities}

Based on the results of observation of student activity in cycle III obtained 10 facets, among others: identifying behavior in the image, explaining the behaviour found in the image, response clarification questions to the cases read out, and respond to the clarification question of the case described, each aspect of the average score of 4.5 or a percentage of $90 \%$, while the aspect of the habituation at the beginning of learning, giving the response of heating/apertion, noting the explanation of material points, record the purpose of learning, conclude the material that has been delivered, and fill the evaluation tool to assess the average score 100 Overall the average score of the implementation of the student's cycle III activity is 4.8 or percentage $96, \%$. When compared with the student activity in cycle II, there is an increase in the $20 \%$ percentage of the II cycle which has a score of 3.8 or $76 \%$ to 4.8 or $96 \%$. This means that the success of the indicator has been achieved with the category "excellent " and exceeds the preset indicators. Overall, students are very interested to follow the process of learning VCT model with the media of the image of wughing so that the level of activity of students category "very good ". Learning outcomes

\section{$>$ Learning Result Cycle I}

Based on the data on the results of the preliminary findings obtained by the data of the classical classifications of $35.29 \%$ or as many as 12 students and who did not complete 22 students or $62.35 \%$ after learning with the implementation of the learning model VCT with the image media on the cycle I obtained the classical guidance of $52.94 \%$ (18 students) increased by $17.65 \%$. This means that the percentage of the classical submission in the I cycle is still far from the set determination indicator that $80 \%$ has not been reached. Based on the students ' learning outcomes, it needs to be further improved in cycle II. Students who are subject to learning should be aware of the importance of learning in the mental learning process of students using their ability to understand the lesson material that the teacher is teaching.

\section{$>$ Learning Results Cycle II}

Based on the results of cognitive cycle II study data, it obtained data on the outcome of the study with the classical guidance of 25 students with a percentage of $73.53 \%$ and who did not complete as many as 9 students with a percentage of $26.47 \%$ increased by $20.59 \%$ compared to the I cycle, thereby the student's cognitive learning outcomes belong to the category "good ". The results that have been achieved in cycle II show that the classical achievement of the success indicator has not been achieved, so it should be extended to the III cycle. The success of learning achieved in cycle II with the application of VCT with a color animated image media shows that learning is more interesting than reading ordinary textbooks and lectures that are only teacher-centered.

\section{$>$ Learning Results Cycle III}

Based on the result data of cognitive cycle III study, then obtained data about the result of learning with the classical guidance 32 students with a percentage of $94.12 \%$ and which is not completed by 2 students with a percentage of $5.88 \%$ increased by $20.59 \%$ compared to cycle II, thereby the student's cognitive learning results are included in the category "very good ". The results that have been achieved in the III cycle demonstrate the classifications of the success indicators achieved, so that the learning can be concluded successfully.

\section{CONCLUSION}

The implementation of the Value Clarification Technique (VCT) learning model is assisted by the image media in PKn subjects with the material to explain the diversity of individuals in daily life can increase the motivation to learn students so that students are more enthusiastic in learning, have confidence in submitting statements and questions about the material, and have initiatives in solving problems. The implementation of the Value Clarification Technique (VCT) learning model is assisted by image media in PKn subjects with the material that explains the individual diversity in daily life can significantly improve student learning outcomes, which includes students ' cognitive learning outcomes. The increase in student learning results can be seen from the average class and the classic percentage of submission achieved by students in cycle I, Cycle II, and cycle III.

\section{SUGGESTION}

We recommend that teachers apply innovative learning models and not always only use lecture methods in PKn-learning. One of the innovative learning models is the implementation of the Value Clarification Technique (VCT) model with Image media assistance, because with the implementation of the VCT learning model in addition to making students active during the learning process can also improve student motivation. With the implementation of innovative learning such as with the implementation of the model Value Clarification Technique (VCT) with the help of image media, the students become more enthusiastic and motivated to follow the learning in the classroom. This is because the teacher will be easier to convey the material of PKn because the model and media used to reduce the gaps that occur due to the understanding of students who are too abstract in the material used. In general, the implementation of the creative and innovative learning and media models one of them is the Value Clarificaation Tekhnique (VCT) model that will impact the students ' learning outcomes, which will indirectly improve the quality of education in the school. In the implementation of learning in class, especially the subjects 
of PKn-Pancasila material and the CONSTITUTION 1945 so that teachers apply the learning model Value Clarification Technique (VCT) with the help of image media so that it can improve student learning results include koglitif.

\section{REFERENCES}

[1]. Adisusilo, S. (2013). Pembelajaran Nilai-Karakter: Konstruktivisme dan VCT Sebagai Inovasi Pendekatan Pembelajaran Afektif. Jakarta: Rajawali Pers.

[2]. Arif S. Sadiman, dkk. (2014). Media pendidikan : pengertian, pengembangan dan pemanfaatannya. Depok: PT. Raja Grafindo Persada.

[3]. Arikunto. (2010). Prosedur Penelitian: Suatu Pendekatan Praktek. Jakarta: Rineka Cipta.

[4]. Arsyad, Azhar. 2016. Media Pembelajaran. Jakarta: Raja Grafindo Persada.

[5]. Darmadi, Hamid. (2010). Pengantar Pendidikan Kewarganegaraan. Bandung: Alfabeta.

[6]. Dimyati dan Mudjiono. 2013. Belajar dan Pembelajaran. Jakarta: Rineka Cipta.

[7]. Fathurrohman. 2011. Pembelajaran PKn di Sekolah Dasar untuk PGSD dan Guru SD. Yogyakarta: Nuha Litera.

[8]. Hamalaik. 2011. Proses Belajar Mengajar. Jakarta: Bumi Raksa.

[9]. John de Santo \& Agus Cremers (ed). 1995. Tahaptahap Perkembangan Moral. Yogyakarta: Kanisius.

[10]. Mardenis. 2017. Pendidikan Kewarganegaraan: Dalam Rangka Pengembangan Kepribadian Bangsa. Jakarta: Rajawali Pers.

[11]. Nurdiansyah dan Eni Fariyarul Fahyuni. 2016. Inovasi Model Pembelajaran, Surabaya: Nizamil Learning Center.

[12]. Rahayudhi, Ni Pt.Yoni A. A. Gd.Agung, dan I Dw. Kade Tastra. 2012. "Pengaruh Model Pembelajaran VCT Berbantuan Media Microsoft Powerpoint Terhadap Prestasi Belajar PKn Siswa Kelas V SD Gugus Ii Kecamatan Tegallalang". Pusat Publikasi Jurnal Universitas Pendidikan Ganesha Jurusan PGSD FIP. 1:2-10

[13]. Rusman. 2017. Belajar dan Pembelajaran Berorientasi Standar Proses Pendidikan. Kencana: Jakarta.

[14]. Sanjaya, Wina. (2014). Strategi Pembelajaran Berorientasi Standar Proses Pendidikan. Jakarta: Kencana Prenada Media.

[15]. Shoimin, Aris. 2014.Model Pembelajaran Inovatif dalam Kurikulum 2013, Yogjakarta: Ar-Ruzz Media.

[16]. Slameto. (2015). Belajar dan Faktor-faktor yang Memengaruhinya. Jakarta: Rineka Cipta.

[17]. Sudjana, Nana. (2016). Penilaian Hasil Proses Belajar Mengajar. Bandung: Rosdikarya.

[18]. Suryabrata, Sumadi. (2012). Metodologi Penelitian. Jakarta : PT. Rajagrafindo Persada

[19]. Susanto, Ahmad. 2013. Teori Belajar dan Pembelajaran di Sekolah Dasar. Jakarta: Prenadamedia Group.
[20]. Taniredja, Tukiran dkk, Model-model Pembelajaran Inovatif dan Efektif, Bandung: Alfabeta, 2017. 